\title{
Fossil Stomatocysts in Upper Cretaceous Sedimentary Pyrite from Central Mexico
}

\author{
Carlos Castañeda-Posadas ${ }^{1}$, Alberto Blanco-Piñón ${ }^{2}$, Juan Hernández-Ávila², \\ Silvia P. Ambrocio-Cruz ${ }^{2}$, Liliana Lizárraga-Mendiola ${ }^{3}$, Susana A. Ángeles-Trigueros ${ }^{4}$ \\ ${ }^{1}$ Laboratorio de Paleontología-Escuela de Biología, Benemérita Universidad Autónoma de Puebla, Puebla, México \\ ²́rea Académica de Ciencias de la Tierra y Materiales, Universidad Autónoma del Estado de Hidalgo, \\ Hidalgo, México \\ ${ }^{3}$ Área Académica de Ingeniería, Universidad Autónoma del Estado de Hidalgo, Hidalgo, México \\ ${ }^{4}$ Instituto de Geología, Universidad Autónoma de San Luis Potosí, San Luis Potosí, México \\ Email: ablanco@uaeh.edu.mx
}

Received December 31, 2013; revised January 28, 2014; accepted February 23, 2014

Copyright (C) 2014 Carlos Castañeda-Posadas et al. This is an open access article distributed under the Creative Commons Attribution License, which permits unrestricted use, distribution, and reproduction in any medium, provided the original work is properly cited. In accordance of the Creative Commons Attribution License all Copyrights (C) 2014 are reserved for SCIRP and the owner of the intellectual property Carlos Castañeda-Posadas et al. All Copyright (C) 2014 are guarded by law and by SCIRP as a guardian.

\begin{abstract}
In this paper six fossil forms of Chrysophycean stomatocysts are described. The material was collected from sedimentary pyrite embedded in well-laminated organic-rich limestone of the Upper Cretaceous Agua Nueva Formation at the locality of Xilitla, Central Mexico. The stomatocysts are represented by two spherical specimens with smooth surfaces lacking of ornamentation, three ovoid forms with rugose textures, one of them exposing presence of pore without collar, and one spherical specimen showing rugose texture and the presence of two short and rounded projections. The specimens here described showed affinity with some stomatocysts morphotypes described for brackish and fresh water, but not for known marine specimens. The presence of these microfossils in the Agua Nueva Formation represents the first formal description of fossil stomatocysts in Upper Cretaceous sedimentary pyrite in Mexico. The occurrence of both micro (planktonic foraminifera, calcispheres, radiolarians) and macrobiota (ammonites, inoceramid bivalves and fishes) and the presence of the specimens in sedimentary pyrite suggest that the stomatocysts were preserved under oxygen-deficiency conditions in a low energy environment. This event could have occurred in open marine waters in the Tampico-Misantla basin (Central Mexico) during the late Cenomanian throughout the early Turonian.
\end{abstract}

\section{KEYWORDS}

Fossil Stomatocysts; Upper Cretaceous; Agua Nueva Formation; Mexico; Sedimentary Pyrite

\section{Introduction}

Fossil biomorphic microstructures in sedimentary pyrite have been reported by several authors since the early 60's [1-11]. Most of the findings of microorganisms in this mineral consist mainly of coccoid bacteria, although bacilli also have been reported. Another kind of structures like pollen [11] and diatoms [12] are less common, whereas reports of cysts [13] are very rare.

Stomatocyst are structures representing a siliceous resting stage produced by Heterokontophyte algae of the classes Chrysophyceae ("golden brown algae") and Synurophyceae [14] commonly referred as Chrysophy- cean algae or simply "Chrysophytes" [15]. They expose a great variety of morphologies consisting of spherical, oval or even pyramidal forms with a single pore $[15,16]$. Globose forms expose a diameter, which ranges from approximately $2-4 \mu \mathrm{m}$ to $30 \mu \mathrm{m}[15,16]$. Surface of stomatocysts also shows presence or absence of ornamentation, and when it is present, it has a wide variation of patterns and structures [17]. So far, more than 400 different morphotypes have been described [14] from several localities in the world; however, in most specimens an accurate taxonomical identification is still necessary $[15,16]$. Commonly, the stomatocysts accumulate in lacustrine sediments $[14,15,18]$, however some speci- 
mens have been described in brackish waters from mangrove habitats of the Caribbean Sea [19] and Central Poland [20]. Reports of stomatocysts in the marine realm are very rare; they are known from sediments of the Caribbean Sea [21], the Southwest Pacific (late Cretaceous, late Eocene and Neogene) [22], the Weddel Sea, Antartica (early Cretaceous: Albian) [23], the Norwegian Sea (Eocene to Pliocene) [24] and the western south Atlantic (Tertiary) [19,20,25]. Some fossils stomatocysts have been reported as minor components in sediments of the Gulf of Mexico, however they were described as freshwater elements [26].

Concerning pyritized forms, a series of pyritized spheres identified as cysts of the genus Tasmanites, a Prasinophycean algae has been reported from the Upper Devonian Chatanooga Shale, at the states of Tennessee and Kentucky, and from other Devonian localities within the state of New York, Unites States of America [13]. This report could represent the only record of pyritized cysts in Devonian sediments in the world. In Mexico, stomatocysts are reported from lacustrine sediments [27] as well as in marine sediments from the Gulf of Mexico area [20]. And so far, no stomatocysts have been reported from sedimentary pyrite in neither lacustrine nor brackish deposits in Mexico; however, a preliminary work [28] reported an unidentified sphere, which is recognized as stomatocyst in this document.

In this paper six biomorphic structures assigned as stomatocysts based on their morphology, size and presence or absence of ornamentation are described. The material here studied was collected from sedimentary pyrite hosted in Upper Cretaceous limestone of the Agua Nueva Formation at the locality of Xilitla, state of San Luis Potosí, Central Mexico (Figure 1).

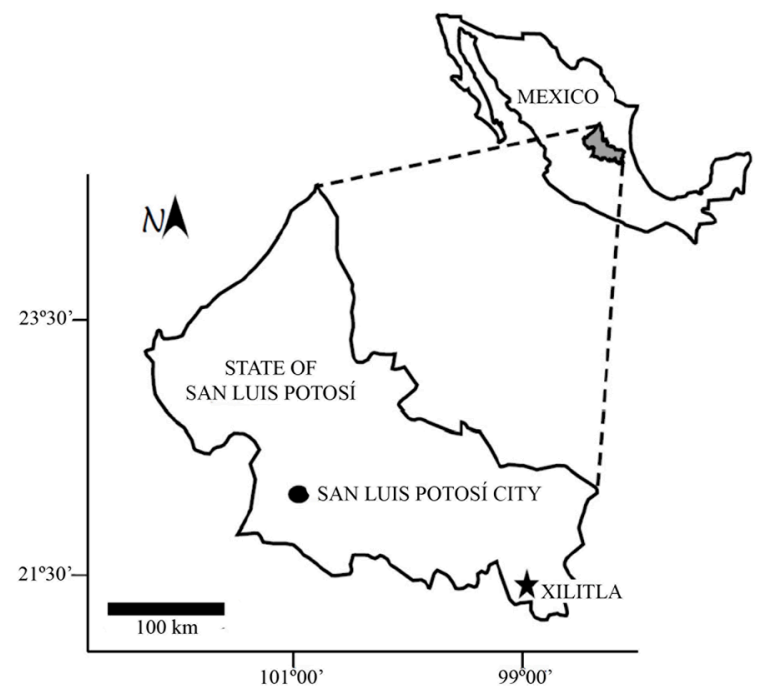

Figure 1. Localization map of Xilitla, state of San Luis Potosí, Central Mexico.

\section{Geological Setting}

Stomatocysts described in this paper have been collected from sedimentary pyrite disposed as millimetric lamina and $2 \mathrm{~cm}$-thick lenses within well-laminated limestone of the Upper Cretaceous Agua Nueva Formation at Xilitla, San Luis Potosí, Mexico. At the study area, this lithostratigraphic unit consists of decimetric limestone alternating with occasional beds of brown shale and green bentonite [11,29-31] (Figure 2). At some levels, limestone exposes parallel lamination at millimetric scale, and bears centimetric layers of black chert as well as millimetric laminae and centimetric lenses of sedimentary pyrite $[10,30,32]$.

This unit is widely distributed in Mexico, and was deposited from the Burgos Basin in northeastern Mexico, through the Tampico-Misantla basin to southern Mexico-
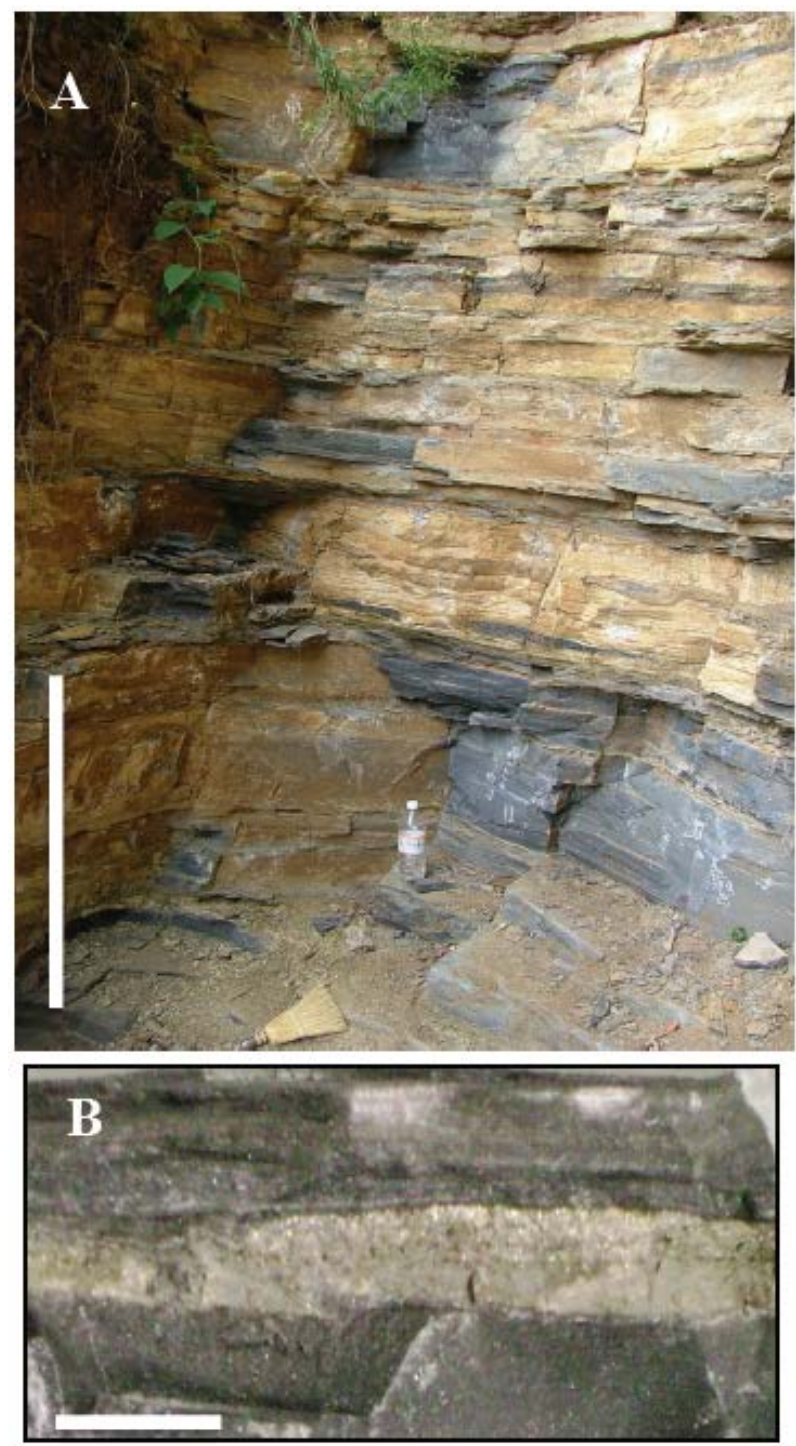

Figure 2. The Agua Nueva Formation at Xilitla, Central Mexico. (A) Outcrop, (B) Layer of sedimentary pyrite. 
during the latest part of the Cenomanian throughout the Turonian [33] (Figure 3). At the locality of Xilitla and its vicinity, this unit has a thickness of approximately $100 \mathrm{~m}$ [34]. According to lithological evidences published by previous works [30,32,35], a deficient concentration of oxygen prevailed at the water sediment interface during the deposition of the laminated-pyrite-bearing limestone of the Agua Nueva Formation, under low energy condi-

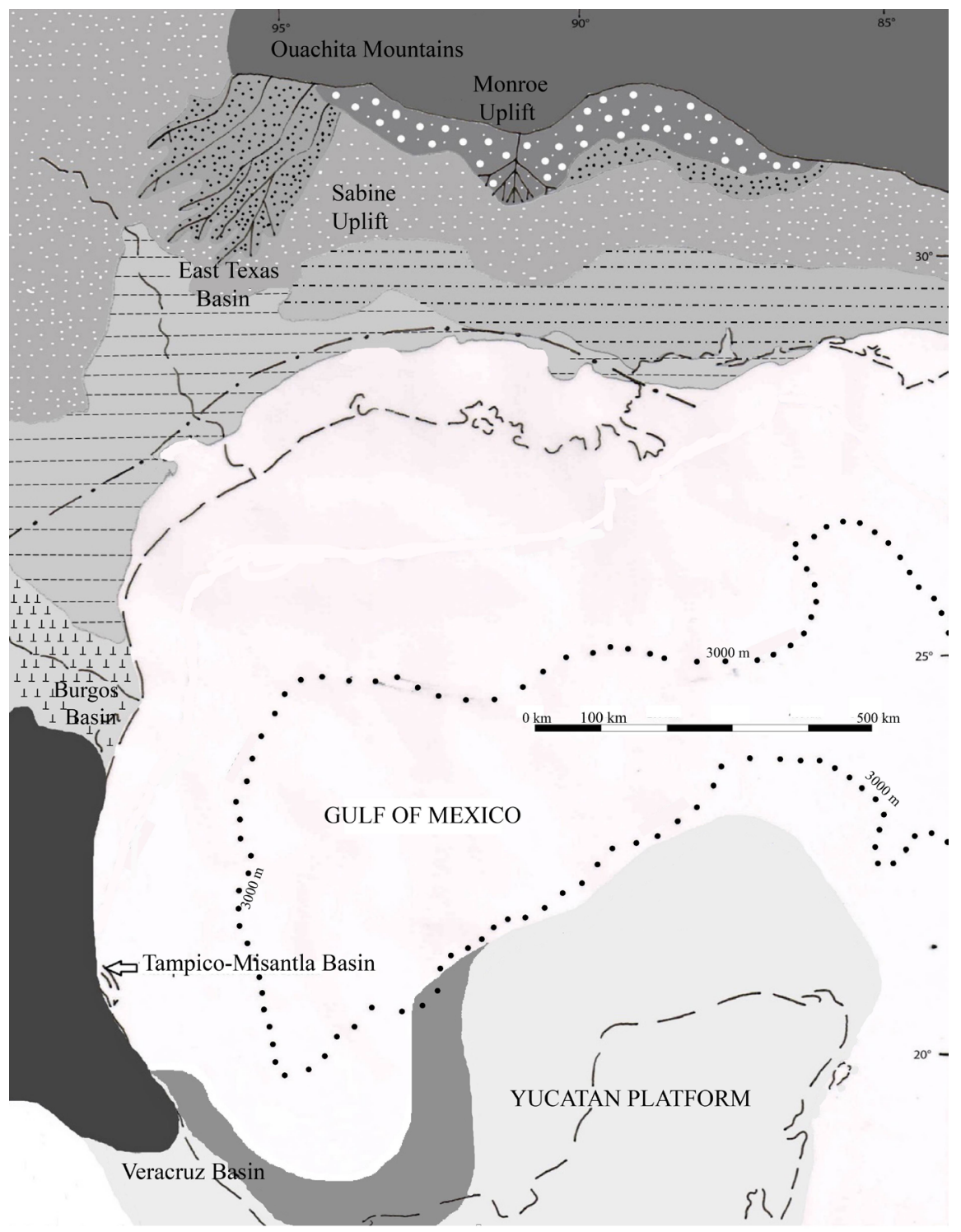

SYMBOLOGY
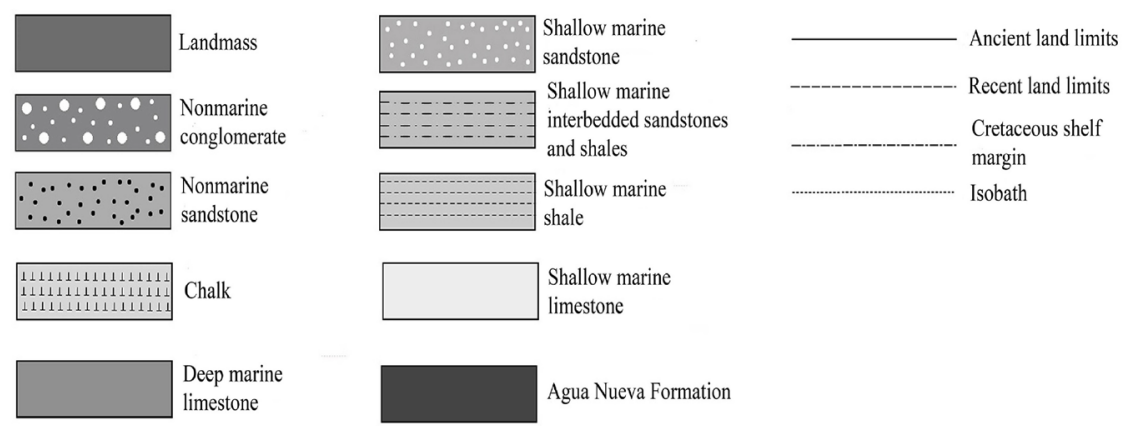

Agua Nueva Formation

Figure 3. Paleogeographic map of the Late Cenomanian throughout the Turonian, modified from [33]. 
tions in the Tampico-Misantla Basin.

\section{Methods}

For observation of pyrite samples in this work, we followed the method used by for previous reports of microorganisms in sedimentary pyrite from the Agua Nueva Formation $[10,11]$. Samples were fractured into fragments of approximately 1 cc. Later, the innermost part of sample was taken in order to avoid any kind of contamination. Samples were gold coated during three minutes. After coating, they were placed into the Scanning Electron Microscope (SEM-JEOL-JSM-6300, resolution of $300,000 \times, 35 \mathrm{kV}$ ) for microscopic observation at the Centro de Investigaciones en Ciencias de la Tierra y Materiales, of the Universidad Autónoma del Estado de Hidalgo.

\section{Description of the Stomatocysts from the Agua Nueva Formation}

A total of 6 forms of chrysophycean stomatocyst were described from the sedimentary pyrite embedded in the limestone of the Agua Nueva Formation cropping out in Xiltla, Central Mexico. They were described and compared on the basis of their morphological characteristics following the criteria established by in the Atlas of Chysophycen Cysts [15], in marsh salt sediments [20] and in the website Stom@tocysts and Co (http://www.stomatocysts.unibe.ch/) [14].

\subsection{Spherical Specimens with Smooth Surface}

Stomatocyst specimen I: (Figure 4(A))

Taxonomic position: Unknown

SEM Description: The specimen 1 is a globose structure with a spherical morphology. It has a width of approximately $8.1 \mu \mathrm{m}$, which is equivalent to the equatorial length, and a total length of $8.3 \mu \mathrm{m}$. It exhibits a smooth surface lacking of any kind of ornamentation or rugose texture. The distal part of the anterior region of the specimen exhibits a pore, which is observed in lateral view and reaches $1.2 \mu \mathrm{m}$ in length. No collar is present around the pore. No more details were observed in this specimen.

Stomatocyst specimen II: (Figure 4(B))

Taxonomic position: Unknown

SEM Description: The specimen 2 is a globose structure with a spherical morphology being slightly wider than longer. It has a length of approximately $7.5 \mu \mathrm{m}$, and a total length of approximately $7.0 \mu \mathrm{m}$, which is equivalent to the equatorial length. The specimen exposes a smooth surface lacking of ornamentation or rugose texture. The distal part of the anterior region of the specimen exhibits a pore, which is notorious only in lateral view. Its shape is not recognizable but in lateral view it has a length
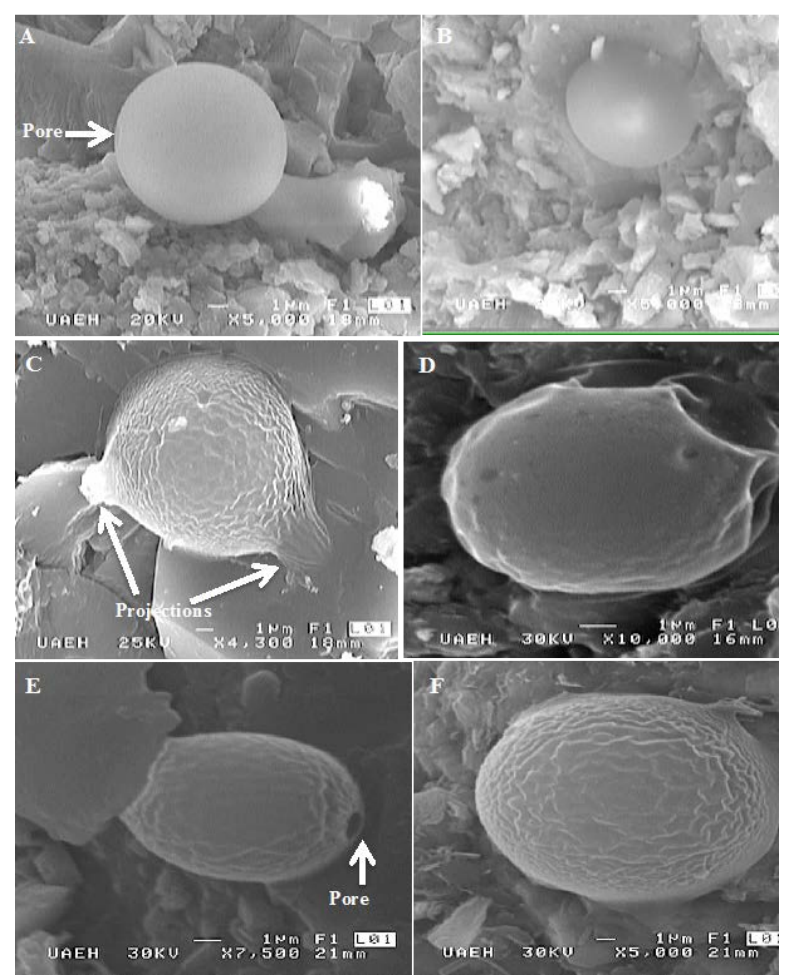

Figure 4. Fossil stomatocysts observed in the sedimentary pyrite from the Agua Nueva Formation at Xilitla, Central Mexico. (A) and (B) Spherical specimens showing smooth surface. (C) Spherical specimen with rugose surface showing proyections; (D) Fragmented oval specimen with smooth surface; (E) and (F) Oval specimens exposing a rugose surface.

of approximately $1.0 \mu \mathrm{m}$. No collar is present around the pore. No more details were observed in this specimen.

\subsection{Spherical Specimens with Rugose Surface}

Stomatocyst specimen III: (Figure 4(C))

Taxonomic position: Unknown

SEM Description: The stomatocyst is quite spherical. It has a diameter varying from $6.4 \mu \mathrm{m}$ in its equatorial portion and $6.8 \mu \mathrm{m}$ in its antero-posterior length. Its surface is not smooth and exhibits a rugose surface. Anteriorly, in lateral view, the specimen exposes a small projection that could represent a collar around the pore, but more details were not observed. In the anterior part of the cyst, at approximately $50^{\circ}$ from the collar, the cyst from Xilitla exposes two protuberances, one of them broken and the other one showing a round distal part. The rounded projection has a length of $1.7 \mu \mathrm{m}$ and a width of $2.5 \mu \mathrm{m}$, whereas the broken structure has a length of 1.4 $\mu \mathrm{m}$ and a width at the base of $1.7 \mu \mathrm{m}$. More details were not detected.

\subsection{Oval Specimens with Smooth Surface}

Stomatocyst specimen IV: (Figure 4(D)) 
Taxonomic position: Unknown

SEM Description: The stomatocyst is oval in shape. Its width (equatorial length) reaches $6.3 \mu \mathrm{m}$ whereas its total length is of $9.8 \mu \mathrm{m}$. Its visible surface is smooth lacking of ornamentation such as projecting structures. The pore is visible in lateral view. Because of the preservation state of the specimen, neither the size nor other morphological features of the pore were estimated.

\subsection{Oval Specimens with Rugose Surface}

Stomatocyst specimen V: (Figure 4(E))

Taxonomic position: Unknown

SEM Description: The stomatocyst is about 1.63 times longer than wider showing an ovoidal morphology. Its width, which seems to be equivalent to the equatorial length, reaches $4.2 \mu \mathrm{m}$, whereas its length reaches 7.2 $\mu \mathrm{m}$. Its surface is not smooth because it exposes a kind of rugose texture along the visible portion of the body, which extends from the anterior to the posterior region. This texture is quite similar than the observed in the specimen III. The cyst lacks of any kind of known ornamentation or projecting structures. The origin of the rugose texture in the surface of the specimen remains unknown. This specimen exhibits a well-exposed circular pore. It is regular and has a diameter of $0.71 \mu \mathrm{m}$. It lacks of a collar, annulus and pseudoannulus.

Stomatocyst specimen VI: (Figure 4(F))

Taxonomic position: Unknown

SEM Description: The stomatocyst is oval in shape with a width (equatorial length) of $5.6 \mu \mathrm{m}$ and an anteroposterior length of approximately $9 \mu \mathrm{m}$. It surface is not smooth, and exposes a kind of rugose aspect covering its whole surface, and lacks of any kind of ornamentation such as reticulum or projecting elements. The anterior pole of specimen bears a pore, which is appreciated in lateral view only. It exposes a length of $0.9 \mu \mathrm{m}$. More details were not observable.

\section{Discussion}

\subsection{The Sedimentary Environment and the Morphological Affinity of the Stomatocysts from Xilitla}

Sedimentary pyrite is a mineral commonly formed under anoxic conditions in both continental and marine environments [36]. Furthermore, these conditions also promote the establishment of well-laminated sediments with high content of organic matter. At the study area, the Agua Nueva Formation exposes such features typically assigned to environments with a deficient concentration of oxygen, such as the presence of well laminated dark micritic limestone, high content of organic matter an relatively well preserved fossil biota [30,31]. As additional data, the fossil biota of the Agua Nueva Formation consists mainly in microfossils corresponding to several forms of planktonic organisms such as globotruncanid and heterohelicid foraminifera, as well as calcispheres and radiolarian mainly. On the other hand, the fossil macrobiota consists of several forms of ammonites, inoceramids as well as fishes that indicate that this lithologic unit was accumulated in open marine waters [29] within a paleogeographic late Cretaceous element known as Cuenca-Tampico-Misantla [33].

Within the sedimentary pyrite embedded in the limestone of the Agua Nueva Formation, the stomatocysts here described were found. According to the morphology, size and presence or absence of ornamentation, the spherical and no ornamented specimens showed some possible affinity with the morphotype 189 . The oval and rugose specimens also have some affinity according to their morphology to morphotypes 118 and/or 121; whereas the spherical and rugose specimen with anterior projections remains unidentified. The stomatocysts are common found in lakes [20], streams [37] and brackish [20] sediments and they are not common in the open marine realm [19]. Spherical and smooth morphologies corresponding to morphotype 189 above enlisted have been largely reported as components of sediments in marsh (brackish) [20] and fresh-water [15] environments. Similar situation has been assigned to the oval morphotypes 118 or 121 that correspond to fresh-water specimens. Reports of stomatocysts in the marine realm consist mainly of Archaeomonads cysts, which have been reported for the Caribbean [21], for the subantarctic Southwest Pacific; Norwegian Sea, and the Atlantic realm [22,24,25]. This group corresponds to planktonic oceanic forms that live in the photic zone and produces well-ornamented cysts, or smooth and spherical forms (e.g. Archaeomonas spherica) with a diameter longer than the $11 \mu \mathrm{m}$, which does not match with any specimens described for the sedimentary pyrite of Xilitla. On the other hand, studies on the distribution of siliceous microfossils in superficial bottom sediments of the Gulf of Mexico [26] also reported the presence of stomatocyst in sediments from the Gulf of Mexico basin, however, they are rare in those deposits and it seem to have a fresh-water origin being transported from continental to marine realms throughout ancient rivers [26]. According to this data, the presence of stomatocyst in the basinal sedimentary pyrite of the Agua Nueva Formation is notable. The Agua Nueva Formation, as mentioned above, was deposited under open marine conditions within the Cuenca TampicoMisantla basin during the late Cenomanian throughout early Turonian [33]. At that time, the input of terrigenous material into the outer shelf and adjacent basinal areas was supplied by deltaic systems established at approximately $1000 \mathrm{~km}$ northward, at the Appalachian and Oachita trends (Figure 3) [33]. This paleogeographic 
arrangement could explain the presence of non-marine stomatocyst in this lithologic unit. However more detailed studies are required to confirm this hypothesis.

\subsection{Pyrite Sedimentary and the Stomatocysts from Xilitla}

Sedimentary pyrite is a mineral, which fossilization potential is relative high and a great diversity of fossils, mainly macrofossils have been collected from sedimentary pyrite in several localities in the world, such as plants and fruits from the Eocene London Clay in England [38] or different groups of metazoans (e.g. nautiloids, conodonts, bivalves and gastropods) from the Late Devonian of Poland [39] among many other famous localities. However, the presence of microscopic elements is less common or even rare. Most of them consist of different morphologies of bacterial remains such as coccoid $[4,5,9,10,28]$, or bacilli [4], or even structures associated to bacterial activity such as piritized discs from Black Meza, Arizona, United States of America [40]. Other kinds of microscopic biostructures are less common or rare, such as diatoms [12], pollen-like structures [11] and cysts [13]. A previous work [28] reported a round and globose unidentified structure from sedimentary pyrite from the Agua Nueva Formation at Xilitla, Central Mexico. This report could represent the first known record of stomatocyst in late Cretaceous marine waters.

\section{Conclusion}

Six forms of stomatocysts were described from Upper Cretaceous sedimentary pyrite of the Agua Nueva Formation in Central Mexico, which were deposited under open marine conditions within the Tampico-Misantla basin (Central-Easthern Mexico) during the late Cenomanian throughout early Turonian. Comparison between the forms of Xilitla and other previously reported show that the Xilitla specimens show more affinities with brackish and fresh-water specimens than with marine species. It suggests that some ancient rivers could supply continental material with stomatocysts into the marine realm. This report could represent the first known record of stomatocyst in Late Cretaceous marine waters.

\section{Acknowledgements}

Special thanks go for Mr. Gustavo Sánchez Juárez (UAEH) for the edition work of the figures showed in this paper. A.B. thanks to Programa al Mejoramiento del Profesorado (PROMEP: Project No. 72636363), and the Consejo Nacional de Ciencia y Tecnología (CONACYT: Project No. 83849) for providing finantial support for fieldwork and collecting data at the locality of Xilitla.

\section{REFERENCES}

[1] J. W. Schopf, E. G. Ehlers, D. V. Stiles and J. D. Birle, "Fossil Iron Bacteria Preserved in Pyrite," Proceedings of the American Philosophical Society, Vol. 109, 1965, pp. 288-308.

[2] J. W. Schopf, "Modes of Fossil Preservation," Review of Paleobotany and Palynology, Vol. 20, No. 1-2, 1975, pp. 27-53. http://dx.doi.org/10.1016/0034-6667(75)90005-6

[3] J. Schieber, "Pyrite Mineralization in Microbial Mats from the Mid-Proterozoic Newland Formation, Belt Supergroup, Montana, U.S.A.," Sedimentary Geology, Vol. 64, No. 1-3, 1989, pp. 79-90. http://dx.doi.org/10.1016/0037-0738(89)90085-7

[4] J. Schieber, "Sedimentary Pyrite: A Window into the Microbial Past,” Geology, Vol. 30, No. 6, 2002, pp. 531534.

http://dx.doi.org/10.1130/0091-7613(2002)030<0531:SP AWIT>2.0.CO;2

[5] J. Schieber, "The Role of an Organic Slime Matrix in the Formation of Pyritized Burrows Trails and Pyrite Concretions,” Palaios, Vol. 17, No. 1, 2002, pp. 104-109. http://dx.doi.org/10.1669/0883-1351(2002)017<0104:TR OAOS $>2.0 . \mathrm{CO} ; 2$

[6] J. Schieber, "Simple Gifts and Hidden Treasures-Implications of Finding Bioturbation and Erosion Surfaces in Black Shales,” The Sedimentary Record, Vol. 1, 2003, pp. 4-8.

[7] J. Schieber, "Granular Microbial Habits Built from Iron Sulfides: Alternative Microbial Lifestyles?” Lunar and Planetary Sciences XXXVI, 2005.

[8] J. Schieber and L. Riciputi, "Pyrite and Marcasite Coated Grains in the Ordovician Winnipeg Formation, Canada: An Intertwined Record of Surface Conditions, Stratigraphic Condensation, Geochemical 'Reworking' and Microbial Activity,” Journal of Sedimentary Research, Vol. 75, No. 5, 2005, pp. 907-920.

http://dx.doi.org/10.2110/jsr.2005.070

[9] R. L. Folk, "Nannobacteria and the Formation of Framboidal Pyrite: Textural Evidence,” Journal of Earth System Science, Vol. 114, No. 3, 2005, pp. 369-374. http://dx.doi.org/10.1007/BF02702955

[10] A. Blanco, F. J. Zavala, J. Hernández-Avila, F. Maurrasse, F. Duque-Botero and M. Ramírez-Cardona, "Microbial Preservation in Sedimentary Pyrite from Cretaceous Organic Matter-Rich Carbonate Mudstone: A Preliminary Report," Lunar and Planetary Science Conference, 2010.

[11] A. Blanco, S. A. Ángeles-Trigueros, C. Castañeda-Posadas and S. P. Ambrocio-Cruz, "Fossilized Pollen Grains in Sedimentary Pyrite and Its Significance for Life Prospection in Mars," Lunar and Planetary Science Conference, 2013.

[12] I. Kaczmarska and J. M. Ehrman, "Pyritized Diatoms in the Sediments of the Distal End of the Bengal Fan,” Proceedings of the Ocean Drilling Project Program, Scientific Results, Vol. 116, 1990, pp. 243-247.

[13] J. Schieber and G. Baird, “On the Origin and Significance of Pyrite Spheres in Devonian Black Shales of North America,” Journal of Sedimentary Research, Vol. 71, No. 
1, 2001, pp. 155-166. http://dx.doi.org/10.1306/051600710155

[14] C. Kamerick, "Stom@ocysts \& Co.-web Application to Bring the Research Community Together via the Internet," Nova Hedwigia, Beiheft, 2010, pp. 311-323.

[15] K. E. Duff, B. A. Zeeb, J. P. Smol and J. R. Glew, “Atlas of Chrysophycean Cysts (Developments in Hydrobiology),” Vol. 1, Kluwer Academic Publishers, Dordrecht, 1994.

[16] C. D. Sandgren and H. J. Carney, “A Flora of Fossil Chrysophycean Cysts from the Recent Sediments of Frains Lake, Michigan, U.S.A.,” Vol. 38, Nova Hedwigia, 1983, pp. 129-163.

[17] P. A. Siver, "The Stomatocyst of Mallomonas v. Muskokana (Chrysophycea),” Journal of Paleolimnology, Vol. 5, No. 1, 1991, pp. 11-17. http://dx.doi.org/10.1007/BF00226556

[18] V. Rull, "Palaeocological Significance of Chryshophycean Stomatocysts: A Statistical Approach,” Hydrobiologia, Vol. 220, No. 2, 1991, pp. 161-165. http://dx.doi.org/10.1007/BF00006549

[19] V. Rull and T. Vegas-Vilarrúbia, "Chrysophycean Stomatocyst in a Caribbean Mangrove," Hydrobiologia, Vol. 428, No. 1, 2000, pp. $145-150$. http://dx.doi.org/10.1023/A:1003967432654

[20] J. Piątek and M. Piątek, "Chrysophyte Stomatocyst of the Sulphuric Salt Marsh in the Owczary Reserve (Central Poland)," Polish Botanical Journal, Vol. 50, No. 1, 2005, pp. 97-106.

[21] G. Deflandre, "Seconde Note sur les Archaeomonadaceés,” Bulletin de la Société Botanique de France, Vol. 80, 1933, pp. 79-90.

[22] K. Perch-Nielsen, "Late Cretaceous to Pleistocene Archaeomonads, Ebridians, Endoskeletal Dinoflagellates and Other Siliceous Microfossils from the Subantarctic Southwest Pacific, DSDP Leg 29," Initial Reports of the Deep Sea Drilling Project, Vol. 29, 1975, pp. 677-722.

[23] D. M. Harwood and R. Gersonde, "Lower Cretaceous Diatoms from Odp Leg 113 Site 693 (Weddell Sea). Part 2: Resting Spores, Chrysophycean Cysts, An Endoskeletal Dinoflagellate and Notes on the Origin Of Diatoms," Proceedings of the Ocean Drilling Program. Scientific Results, Vol. 113, 1990, pp. 403-425.

[24] K. Perch-Nielsen, "Eocene to Pliocene Archaeomonads, Ebridians and Endoskeletal Dinoflagellates from the Norwegian Sea, DSDP Leg 38," Initial Reports of the Deep Sea Drilling Project, Vol. 38, 1975, pp. 147-175

[25] K. Perch-Nielsen, "Tertiaty Silicoflagelates and other Siliceous Microfossils from the Westerm South Atlantic Deep Sea Drilling Project. Leg 39,” Initial Reports of the Deep Sea Drilling Project, Vol. 39, 1977, pp. 863-867. http://dx.doi.org/10.2973/dsdp.proc.39.135.1977

[26] J. P. Jendrzejewski and G. F. Hart, "Distribution of Siliceous Microfossils in Superficial Bottom Sediments of the Gulf of Mexico,” Palynology, Vol. 2, No. 1, 1978, pp. 159-166. http://dx.doi.org/10.1080/01916122.1978.9989170

[27] L. Sanchez, R. Rico-M, M. R. Fernández and J. Cañetas,
"Estomatoquistes Fósiles de Crisofíceas de El Arenal Jalisco, México," Revista Chapingo Serie Ciencias Forestales y del Ambiente, Vol. 6, No. 2, 2000, pp. 93-102.

[28] S. A. Ángeles-Trigueros, A. Blanco-Piñón, J. HernándezÁvila and F. J. Zavala-Díaz de la Serna, "Bioformas Microscópicas en Pirita Sedimentaria y sus Implicaciones Astrobiológicas,” Memorias de la VIII Reunión de la Sociedad Mexicana de Astrobiología, Cuernavaca, 4th August, 2012, pp. 59-62.

[29] A. Blanco-Piñón, F. J.-M. R. Maurrasse and F. DuqueBotero, "Cyanobacteria/Foraminifera Association from Anoxic/Dysoxic Beds of the Agua Nueva Formation (Upper Cretaceous-Cenomanian/Turonian) at Xilitla, San Luis Potosi, Central Mexico,” Eos Transactions AGU, Vol. 89, No. 23, 2008, pp. 24A-04.

[30] A. Blanco, F. Maurrasse, F. Duque-Botero and A. Delgado-Angeles, "Anoxic-Dysoxic-Oxic Conditions in the Cenomanian Agua Nueva Formation (Upper Cretaceous) in Central Mexico and Their Relation to Oceanic Anoxic Event 2 (OAE 2)," Geological Society of America, Abstracts with Programs, Vol. 43, No. 5, 2011, p. 421.

[31] A., Blanco-Piñón, S. A. Ángeles-Trigueros, J. HernándezÁvila and F. J. Zavala-Díaz de la Serna, "SEM Imaging of Biostructures in Upper Cretaceous Sedimentary Pyrite: an Astrobiological Approach," Geological Society of America, Abstracts with Programs, Vol. 44, No. 7, 2012, p.75.

[32] A. Blanco-Piñón, F. J. Zavala-Díaz de la Serna, J. Hernández-Ávila, F. Maurrasse and F. Duque-Botero, "Microscopic Bioforms in Pyritic Layers from the Cenomanian/Turonian (Upper Cretaceous) Agua Nueva Formation, Xilitla, Central Mexico: A Preliminary Description,” Geological Society of America, Abstracts with Programs, Vol. 41, No. 7, 2009, p. 82.

[33] N. F. Sohl, E. Martínez, P. Salmerón-Ureña and F. SotoJaramillo, "Upper Cretaceous,” In: A. Salvador Ed., The Gulf of Mexico Basin, The Geological Society of North America, Austin, 1991, pp. 205-242

[34] M. Suter, “Carta Geológica de México. Hoja Tamazunchale 14Q-e(5) Escala 1:1000.000,” Universidad Nacional Autónoma de México, Instituto de Geología, México, D.F., 1991.

[35] F. J.-M. R. Maurasse, F. Duque-Botero and A. BlancoPiñón, "Oceanic Anoxic Event 2 (OAE-2) in Cretaceous Northeastern Mexico and the Effects of Paleophysiography at the Sediment Record,” In: M. A. Lamolda, E. Díaz, G. Jiménez-Moreno, F. J.-M. R. Maurrasse, G. Meléndez, C. R. C. Paul and F. J. Rodríguez-Tovar, Eds., Geoevents, Geological Heritage and the Role of the IGCP, Caravaca de la Cruz, 2010, pp. 54-62.

[36] R. A. Berner, "Sedimentary Pyrite Formation: An Update," Geochimica et Cosmochimica Acta, Vol. 48, No. 4, 1984, pp. 605-615. http://dx.doi.org/10.1016/0016-7037(84)90089-9

[37] T. Mrozińska, M. Olech and A. Massalski, "Cyst of the Chrysophyceae from King George Island (South Shetland Islands, Antartica),” Polish Polar Research, Vol. 19, No. 3/4, 1998, pp. 205-210.

[38] S. T. Grimes, K. L. Davies, I. B. Butler, F. Brock, D. 
Edwards, D. Rickard, D. E. G. Briggs and R. K. Parkes, "Fossil Plants from the Eocene London Clay: the Use of Pyrite Textures to Determine the Mechanism of Pyritization,” Journal of the Geological Society, Vol. 159, 2002, pp. 493-501. http://dx.doi.org/10.1144/0016-764901-176

[39] E. Jag-Yazikova, W. Krawczyński and M. Rokocińsky, "Molluscs from the Early Frasnian Goniatite Level at Kostomłoty in the Holy Cross Mountains, Poland," Acta
Palaeontologica Polonica, Vol. 51, No. 4, 2006, pp. 707718.

[40] G. Southam, R. Donald, A. Röstad and C. Brock, "Pyrite Discs in Coal: Evidence for Fossilized Bacterial Colonies," Geology, Vol. 29, No. 1, 2001, pp. 47-50.

http://dx.doi.org/10.1130/0091-7613(2001)029<0047:PDI $\mathrm{CEF}>2.0 . \mathrm{CO} ; 2$ 